\title{
Impact of germination on the nutritional, antioxidant and antinutrient characteristics of selected minor millet flours
}

\author{
Shreeja Kulla , T.V. Hymavathi, B. Anila Kumari, R. Geetha Reddy ** and Ch.V. Durga Rani *** \\ Foods and Nutrition, PG and RC, PJTSAU, Rajendranagar, Hyderabad-500030, T.S., India \\ **Extension Education and Communication Management, College of Home Science, PJTSAU, Saifabad, Hyderabad-500004, T.S., India \\ ***Molecular Biology and Biotechnology, Institute of Biotechnology, PJTSAU, Rajendranagar, Hyderabad-500030, T.S., India
}

\section{Article Info}

Article history

Received 4 April 2021

Revised 25 May 2021

Accepted 30 May 2021

Published online 30 June 2021

\section{Keywords}

Barnyard millet

DPPH scavenging activity

Processing

Proximate composition

Small millets

Sprouting

Total phenolic content

\begin{abstract}
The present study was conducted to evaluate the effect of germination on nutritional, antinutritional, total phenolic content, total flavonoid content and antioxidant activity (DPPH radical scavenging activity) in barnyard, foxtail and little millet flours. Grains were germinated for $24 \mathrm{~h}$ after soaking for $12 \mathrm{~h}$, dried, milled and used for the analysis. Nutritional composition of millet flours was analyzed using AOAC methods. Antinutritional and antioxidant properties were measured in terms of oxalates, tannins, total phenolic contents and total flavonoid contents. Antioxidant activity was done using DPPH radical scavenging activity at six different concentrations and $50 \%$ inhibitory concentration was drawn from the linear regression. Germination of millets has decreased energy value and oxalate content, and increased crude fiber, tannins, total phenolic compounds and total flavonoid compounds. It also increased DPPH radical scavenging activity of millet flours. As germinated millet flours are rich source of antioxidant properties with good radical scavenging activity could be recommended to develop functional foods for the treatment of various degenerative diseases.
\end{abstract}

\section{Introduction}

There are increasing evidences worldwide that free radicals produce molecular alterations in human cells that are correlated with various degenerative diseases such as atherosclerosis, cancers, parkinson's disease, diabetes, asthma, alzheimer's disease, arthritis, immune deficiency diseases and ageing (Okoh et al., 2014; Sen et al., 2010) which can be reduced by health promoting diets including millets, fruits and vegetables. Millets are the most commonly consumed food items in India, Africa, China and elsewhere. They contain wide range of high-quality protein with good amino acid balance, fibre, magnesium, manganese, niacin, phosphorus, iron, potassium, B-complex vitamins, vitamin A and E (Shashi et al., 2007; Saleh et al., 2013). Millets are also natural source of many bioactive compounds including phenolic acids, athocyanins and flavonols which possess antioxidant properties and can act as nutraceutical and functional food ingredient in health promotion and risk reduction in degenerative diseases (Kayode et al., 2007; Rao et al., 2011; Sreeramulu et al., 2009). Millets are least allergenic, non-glutinous, non-acid forming and easy to digest. All these make millets an important nutritional biosource and, hence termed as nutracereal (Devi et al., 2014; Nazni and Shobana, 2016).

The main drawback of millet nutrition is its bioavailability owing to high antinutritional factors which can be reduced by various traditional

Corresponding author: Ms. Shreeja Kulla

Foods and Nutrition, $P G$ and RC, PJTSAU, Rajendranagar, Hyderabad-500030, T.S., India

E-mail: shreeja.sri25@gmail.com

Tel.: +91-9849893257

Copyright (C) 2021 Ukaaz Publications. All rights reserved.

Email: ukaaz@yahoo.com; Website: www.ukaazpublications.com processing techniques (Sheela et al., 2018). Soaking followed by germination improves nutrient levels of millets by activating hydrolytic enzymes, endo and exopeptidases. Germinated grains contain low unsaturated fatty acids, high protein, vitamins, minerals such as calcium, phosphorus, copper and zinc than ungerminated grains (Dicko et al., 2006; Inyang and Zakari, 2008). Several studies on germination of pearl and sorghum millets have shown lessened antinutritional factors (Elmaki et al., 1999; Nwasike, 1989; Correia et al., 2010); increased nutritive value (Correia et al., 2008; Nkama et al., 2015) and minerals (Badau et al., 2005; Arora et al., 2003; Suma and Urooj, 2014). Very less research works has been done on the nutritional changes occurring in minor millets after germination, so the aim of the present study is to investigate the effect of germination on proximate composition, antinutrients, total phenolic content, total flavonoid content and antioxidant activity including $50 \%$ inhibitory concentrations in barnyard, foxtail and little millets.

\section{Materials and Methods}

\subsection{Procurement and germination}

Barnyard, foxtail and little millet were procured directly from the farmers. Barnyard and little millet grains were germinated at $35^{\circ} \mathrm{C}$ and foxtail millet at $30^{\circ} \mathrm{C}$ for $24 \mathrm{~h}$ in BOD incubator after overnight steeping in distilled water. Germination time and temperature were optimized according to Al-Mudaris (1998). Then, the germinated grains were dried in tray dryer at $60^{\circ} \mathrm{C}$ for $6 \mathrm{~h}$. Dried germinated grains and raw grains were milled and stored in an air tight bag for further analysis. 


\subsection{Proximate analysis}

Proximate composition of raw and germinated millet flours was done using standard AOAC methods such as moisture-oven drying method (AOAC, 2005), ash-charring method (AOAC, 2005), protein-kjeldhal method (AOAC 992.23 - 2005), crude fiber-acid-base extraction method (AOAC 962.09 - 2016) and fat-soxhlet extraction method (AOAC 922.06 - 2016). Carbohydrate content was calculated by subtracting the total of moisture, fat, protein, and ash from 100 . Energy values were obtained by the formula:

Energy value $=$ Protein $\times 4+$ Carbohydrate $\times 4+$ Fat $\times 9$.

\subsection{Antinutrient analysis}

Tannins were analyzed spectrophotometrically at $700 \mathrm{~nm}$ by using tannic acid as standard. Titration method was used to determine oxalate content. One gram of the sample was weighed into $100 \mathrm{ml}$ conical flask where $75 \mathrm{ml}$ of $3 \mathrm{M} \mathrm{H}_{2} \mathrm{SO}_{4}$ was added and stirred intermittently with a magnetic stirrer for $1 \mathrm{~h}$. It was then filtered using Whatman No.1 filter paper. From the filtrate, $25 \mathrm{ml}$ was taken and titrated against hot $\left(80-90^{\circ} \mathrm{C}\right) 0.1 \mathrm{~N} \mathrm{KMnO}_{4}$ solution up to faint pink color persisted for at least $30 \mathrm{~s}$ (Nissar et al., 2017).

\subsection{Antioxidant properties and antioxidant activity}

Samples were extracted using cold maceration technique in methanol $(1 \mathrm{~g} / 100 \mathrm{ml})$ for $24 \mathrm{~h}$ then centrifuged at $3000 \mathrm{rpm}$ for $30 \mathrm{~min}$, filtered through Whattman number 41 filter paper and extracts were preserved at $4^{\circ} \mathrm{C}$ to analyze TFC (Total Flavonoid Content), TPC (Total Phenolic Content) and antioxidant activity. TPC and TFC were done spectrophotometrically at 750 and $415 \mathrm{~nm}$ and expressed in GAE (Gallic Acid Equivalents) and RE (Rutin Equivalents), respectively (Slinkard and Slingleton, 1997; Meda et al., 2005). Antioxidant activity was determined using DPPH radical scavenging activity at different concentrations such as 1,2, 4, 6, 8, $10 \mathrm{mg}$ and absorbance was read at $517 \mathrm{~nm}$ (Domain et al., 2004). Inhibitory concentration of $50 \%\left(\mathrm{IC}_{50}\right)$ was obtained by interpolation of linear regression analysis from the data obtained at various concentrations.

\subsection{Statistical analysis}

Experiments were carried out in triplicates. Data was subjected to CRD-ANOVA to determine significant difference between group means at $5 \%$ level of significance using Windostat version 9.1.

\section{Results}

\subsection{Effect of germination on proximate composition}

Data pertaining to proximate composition and per cent change of raw and germinated millet flours have been given in Table 1, and Figure 1 on dry weight basis. From the Table 1 it can be seen that moisture content ranged from 8.52 to $7.41 \%$ with the highest content in WBF (Whole Barnyard millet Flour), followed by WLF (Whole Little millet Flour), WFF (Whole Foxtail millet Flour), GBF (Germinated Barnyard millet Flour), GFF (Germinated Foxtail millet Flour) and GLF (Germinated Little millet Flour). Germination has shown non-significant effect of moisture levels in barnyard and foxtail millet flour, but it significantly decreased in little millet flour by $11.07 \%$. Protein content of the millet flours ranged from 12.05 to $10.19 \%$. The crude protein content was highest in little millet (12.05 and $11.14 \%$ ), followed by foxtail (11.14 and $10.75 \%)$ and barnyard millet (10.19 and $10.9 \%)$ of raw and germinated millet flours. Ash content was ranged between 4.99 to $3.25 \%$. Significant difference was found among the three germinated millet flours, even though there was no difference in raw foxtail and little millet flours. It might be due to increase in ash content of WLF than the WFF (Figure 1). Crude fiber content of samples ranged from 11.21 to $7.96 \%$. Germination has significantly increased crude fiber content in barnyard and foxtail millet, while no significant increase was found in little millet. Crude fiber content was increased by 12.1, 8.66 and $4.29 \%$ in GBF, GFF and GLF, respectively. It was highest in GBF (Figure 1) as crude fiber is high in raw barnyard millet flour. Fat content of all flour samples was in the range of 5.29 to $3.5 \%$; it was highest in GLF, followed by WBF, GBF, WFF, WLF and GFF (Table 1). Carbohydrates of raw and germinated millet flours ranged from 66.44 to $60.55 \%$. Carbohydrate content was highest in foxtail millet ( 65.59 and $66.44 \%$ ) followed by little ( 63.3 and $63.58 \%$ ), and barnyard millet (65.59 and 66.44\%) among raw as well as germinated millet flours. Energy values ranged from 346 to $327 \mathrm{Kcal}$ with GLF and WFF having the highest value, followed by GFF, WLF, WBF and GBF.

WBF: Whole barnyard millet flour; WFF: Whole foxtail millet flour; WLF: Whole little millet flour; GBF: Germinated barnyard millet flour; GFF: Germinated foxtail millet flour; GLF: Germinated little millet flour. The results are given as Means \pm SD of three measurements. Means within a column with the same superscript alphabet are not significantly different $(p<0.05)$.

Table 1: Effect of germination on proximate composition of minor millets

\begin{tabular}{|c|c|c|c|c|c|c|c|}
\hline & Moisture (\%) & Ash (\%) & Protein (\%) & Crude fiber (\%) & Fat $(\%)$ & CHO (\%) & Energy (Kcal) \\
\hline WBF & $8.52 \pm 0.04^{\mathrm{a}}$ & $4.97 \pm 0.03^{\mathrm{a}}$ & $10.19 \pm 0.27^{\mathrm{c}}$ & $10 \pm 0.24^{\mathrm{b}}$ & $4.898 \pm 0.11^{\mathrm{b}}$ & $61.42 \pm 0.19^{\mathrm{d}}$ & $331 \pm 0.84^{c}$ \\
\hline WFF & $7.81 \pm 0.06^{\mathrm{ab}}$ & $3.24 \pm 0.03^{c}$ & $11.14 \pm 0.15^{b}$ & $7.96 \pm 0.2^{\mathrm{d}}$ & $4.26 \pm 0.06^{\mathrm{d}}$ & $65.59 \pm 0.3^{b}$ & $345 \pm 1.13^{\mathrm{a}}$ \\
\hline WLF & $8.49 \pm 0.66^{\mathrm{a}}$ & $3.36 \pm 0.01^{\mathrm{bc}}$ & $12.05 \pm 0.43^{\mathrm{a}}$ & $8.61 \pm 0.26^{\mathrm{c}}$ & $4.2 \pm 0.04^{\mathrm{d}}$ & $63.3 \pm 0.76^{c}$ & $339 \pm 1.64^{\mathrm{b}}$ \\
\hline GBF & $7.81 \pm 0.04^{\mathrm{ab}}$ & $4.99 \pm 0.03^{\mathrm{a}}$ & $10.9 \pm 0.05^{\mathrm{b}}$ & $11.21 \pm 0.1^{\mathrm{a}}$ & $4.54 \pm 0.07^{\mathrm{c}}$ & $60.55 \pm 0.13^{\mathrm{d}}$ & $327 \pm 0.34^{\mathrm{d}}$ \\
\hline GFF & $7.41 \pm 0.04^{\mathrm{b}}$ & $3.25 \pm 0.003$ & $10.75 \pm 0.1^{\mathrm{b}}$ & $8.65 \pm 0.18^{c}$ & $3.50 \pm 0.09^{\mathrm{e}}$ & $66.44 \pm 0.15^{\mathrm{a}}$ & $340 \pm 0.17^{\mathrm{b}}$ \\
\hline GLF & $7.55 \pm 0.09^{b}$ & $3.48 \pm 0.03^{\mathrm{b}}$ & $11.14 \pm 0.15^{b}$ & $8.98 \pm 0.21^{\mathrm{c}}$ & $5.29 \pm 0.12^{\mathrm{a}}$ & $63.58 \pm 0.08^{c}$ & $346 \pm 0.8^{\mathrm{a}}$ \\
\hline CD at $5 \%$ & 0.75 & 0.127 & 0.586 & 0.57 & 0.222 & 0.982 & 2.646 \\
\hline CV \% & 3.68 & 1.27 & 2.07 & 2.4 & 1.94 & 0.6 & 0.3 \\
\hline
\end{tabular}




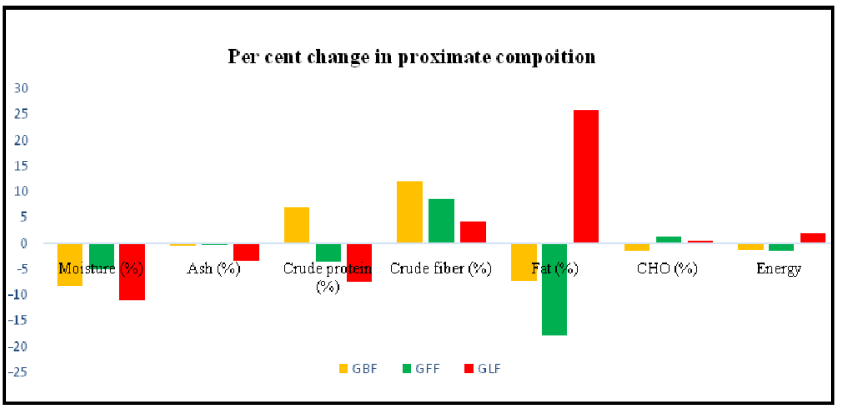

Figure 1: Per cent change in proximate composition of millet flours on germination.

GBF: Germinated barnyard millet flour; GFF: Germinated foxtail millet flour; GLF: Germinated little millet flour.

3.2 Effect of germination on antinutritional and antioxidant properties

Antinutritional and antioxidant properties of millet flour obtained from raw millets and germinated millets was presented in Table 2. Oxalate content has nutritional importance due to interference with mineral (calcium) bioavailability. Khokhar and Apenten (2003) opined the removal of oxalates to a safe level via the germination process. Oxalate content of millet flours was ranged from 0.56 to $0.37 \mathrm{~g} / 100$ $\mathrm{g}$ with the highest content in WFF, followed by WLF, GBF, WBF, GFF and GLF. From Table 2, it can be seen that tannin content of millet flours was ranged from 9.1 to $4.72 \%$. Tannins were high in little millet (6.14 and 9.1\%), followed by foxtail (4.94 and $6.27 \%$ ) and barnyard millet (4.72 and $5.78 \%$ ) ) both in raw and germinated millet flours.

Total phenolic compounds of millet flours ranged from 55.98 to $132.98 \mathrm{mg} \mathrm{GAE} / 100 \mathrm{~g}$ with the highest content in WLF, followed by GLF, GBF, GFF, WBF and WFF 123.3, 105.83, 69.28, 66.78 and 55.98 mg GAE/100 g, respectively. Total flavonoid content of millets ranged from 699.76 to $1343 \mathrm{mg} \mathrm{RE} / 100 \mathrm{~g}$ with the highest content in GFF, followed by WFF, GLF, GBF, WLF and WBF (Table 2). Total flavonoid content of $27 \mathrm{RE} \mathrm{mg/g}$ in pearl millet and $391 \mathrm{RE} \mathrm{mg} / 100 \mathrm{~g}$ in roasted proso millet were reported by Pushparaj and Urooj (2014) and Kalam Azad et al. (2019), respectively per cent increase in total flavonoid content after germination was 22.81, 11.9 and 34.81 in barnyard, foxtail and little millet, respectively.

Table 2: Effect of germination on antinutrient and antioxidant properties of minor millets

\begin{tabular}{|c|c|c|c|c|}
\hline & Oxalates $(\mathrm{g} / 100 \mathrm{~g})$ & Tannins (\%) & TPC (mg GAE/100 g) & TFC (mg RE/100 g) \\
\hline WB F & $0.44 \pm 0.004^{\mathrm{b}}$ & $4.72 \pm 0.09^{\mathrm{e}}$ & $66.78 \pm 3.85^{\mathrm{d}}$ & $699.76 \pm 20.51^{\mathrm{e}}$ \\
\hline WFF & $0.56 \pm 0.004^{\mathrm{a}}$ & $4.94 \pm 0.12^{\mathrm{e}}$ & $55.98 \pm 0.39^{\mathrm{e}}$ & $1200.08 \pm 65.76^{b}$ \\
\hline WLF & $0.44 \pm 0.004^{b}$ & $6.14 \pm 0.06^{\mathrm{c}}$ & $132.98 \pm 7.74^{\mathrm{a}}$ & $743.7 \pm 29.87^{\mathrm{e}}$ \\
\hline GB F & $0.44 \pm 0.001^{\mathrm{b}}$ & $5.78 \pm 0.09^{\mathrm{d}}$ & $105.83 \pm 0.88^{c}$ & $859.44 \pm 30.32^{\mathrm{d}}$ \\
\hline GFF & $0.37 \pm 0.004^{\mathrm{c}}$ & $6.27 \pm 0.04^{\mathrm{b}}$ & $69.28 \pm 1.24^{\mathrm{d}}$ & $\pm 38.18^{a}$ \\
\hline GLF & $0.37 \pm 0.004^{\mathrm{c}}$ & $9.1 \pm 0.06^{\mathrm{a}}$ & $123.3 \pm 1.84^{b}$ & $1002.65 \pm 26.38^{c}$ \\
\hline CD at $5 \%$ & 0.003 & 0.225 & 10.28 & 80.439 \\
\hline CV \% & 0.25 & 1.43 & 4.33 & 3.21 \\
\hline
\end{tabular}

WBF: Whole barnyard millet flour; WFF: Whole foxtail millet flour; WLF: Whole little millet flour; GBF: Germinated barnyard millet flour; GFF: Germinated foxtail millet flour; GLF: Germinated little millet flour. TPC: Total phenolic content, TFC: Total flavonoid content, GAE: Gallic acid equivalent, RE: Rutin equivalent. The results are given as Means \pm SD of three measurements. Means within a column with the same superscript alphabet are not significantly different $(p<0.05)$

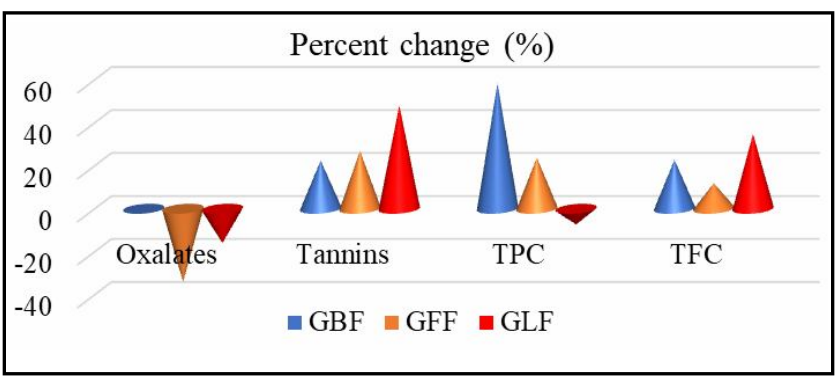

Figure 2: Percent change in antinutrient and antioxidant properties on germination.

GBF: Germinated barnyard millet flour; GFF: Germinated foxtail millet flour; GLF: Germinated little millet flour.
3.3 Germination effect: Antioxidant activity by DPPH radical scavenging activity and $\mathrm{IC}_{50}$

Figures 3-5 summarizes data on DPPH radical scavenging activity of raw and germinated millet flours. $\mathrm{IC}_{50}$ values were presented in Figure 6. In the DPPH scavenging assay, the color stable DPPH radical is brought down in the presence of an antioxidant which donates hydrogen to non-radical DPPH-H (Ragaee et al., 2006). $\mathrm{IC}_{50}$ values of barnyard millet was increased on germination from 2.72 to 3.31 $\mathrm{mg} / \mathrm{ml}$ (Figure 4) which means WBF has higher scavenging activity than GBF. Inhibition per cent was increased with an increase in the concentration in barnyard millet, it is high in GBF up to $6 \mathrm{mg}$ and later it raised but not more than WBF (Figure 3). Decreased scavenging activity was reported after germination in two pearl millet varieties (Pushparaj and Urooj, 2014). Radical scavenging activity has significantly increased in GFF than WFF at all the concentrations (Figure 4). $\mathrm{IC}_{50}$ value in GFF $(3.61 \mathrm{mg} / \mathrm{ml})$ was slightly higher than raw foxtail millet flour $(3.51 \mathrm{mg} / \mathrm{ml})$. Germinated little millet also has shown a significant increase in free radical scavenging activity at all the concentrations than WLF (Figure 5). The same was observed in $50 \%$ inhibitory concentration of free radicals $(1.92$ and $1.99 \mathrm{mg} / \mathrm{ml})$ (Figure 6). Effect of germination on DPPH radical scavenging activity in the barnyard, foxtail and little millet (Figures 3-5). 


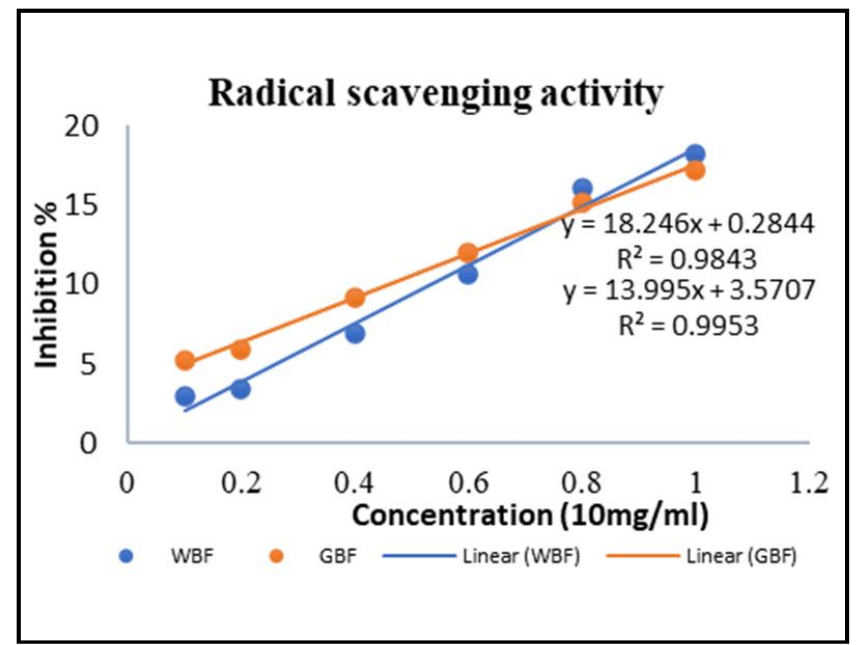

Figure 3: Barnyard millet.

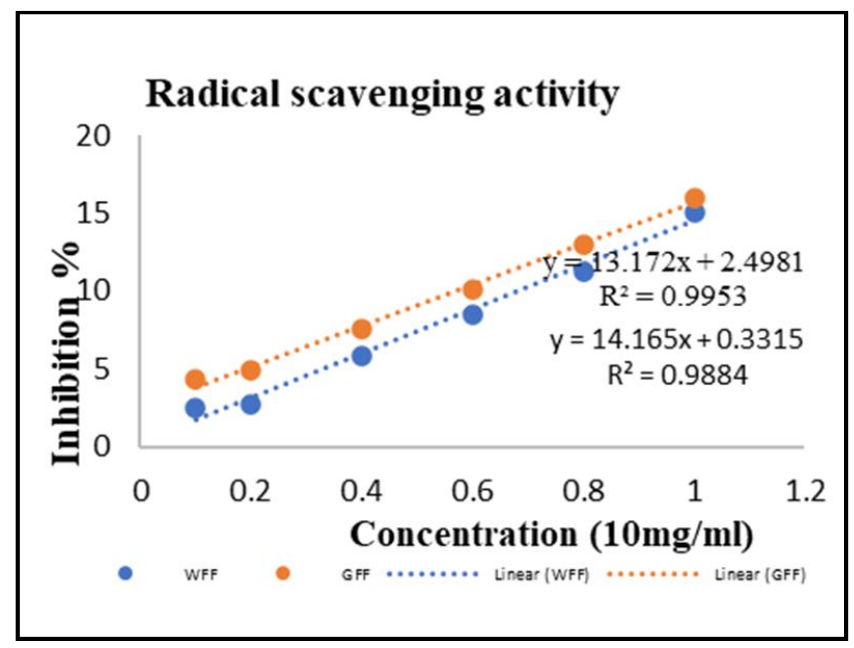

Figure 4: Foxtail millet.

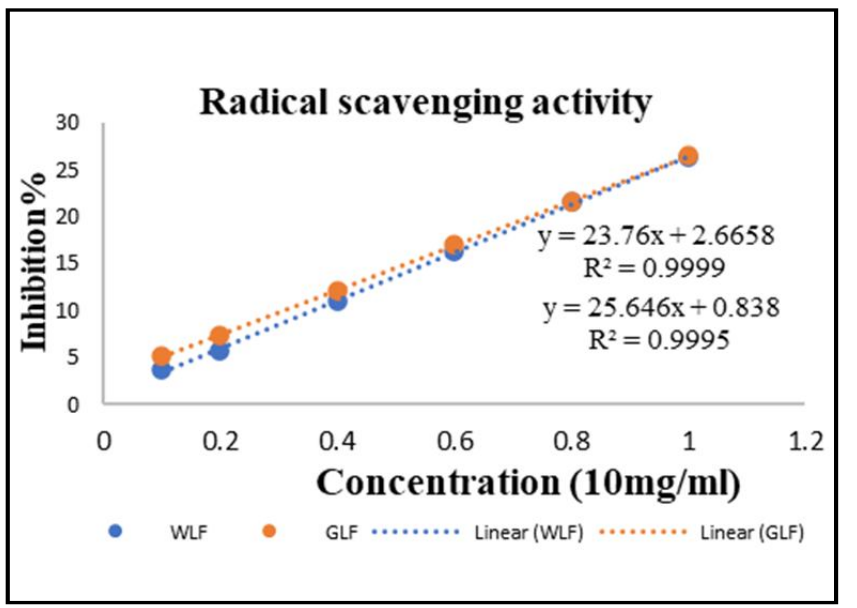

Figure 5: Little millet.

WBF: Whole barnyard millet flour; WFF: Whole foxtail millet flour; WLF: Whole little millet flour; GBF: Germinated barnyard millet flour; GFF: Germinated foxtail millet flour; GLF: Germinated little millet flour.

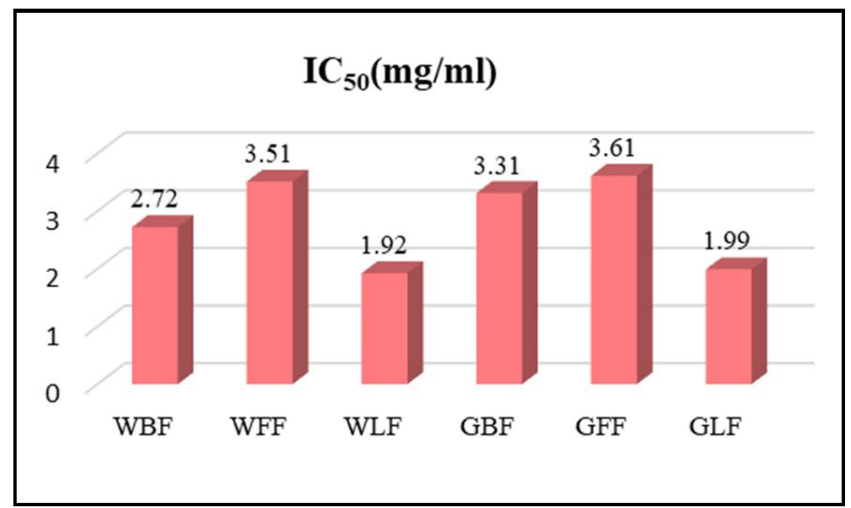

Figure 6: Effect germination on $50 \%$ inhibitory concentration in minor millets.

WBF: Whole barnyard millet flour; WFF: Whole foxtail millet flour; WLF: Whole little millet flour; GBF: Germinated barnyard millet flour; GFF: Germinated foxtail millet flour; GLF: Germinated little millet flour.

\section{Discussion}

Moisture content has significantly decreased in little millet and no difference was observed in barnyard and foxtail millet on germination. Similar results were reported in pearl millet, finger millet, sorghum (Singh et al., 2017), maize (Anaemene and Fadupin, 2020) and green gram (Dattatray et al., 2019) after germination. Due to the drying process in flour development, lower moisture levels help in longer shelf life of flours. Germination has shown an effect on crude protein content; it significantly increased in barnyard millet $(6.96 \%)$ and decreased in little millet $(7.55 \%)$. Germination of pearl millet has increased protein content; it might be due to enzymatic synthesis (Sade, 2009). In contrast, no difference was found in foxtail millet. Similar observations were reported by Xu et al. (2012) in germinated brown rice. Germination has shown a non-significant decrease in ash content of millet flours. Other authors observed similar results in pearl millet after germination (Suma and Urooj, 2014; Sade, 2009). The reduction could be due to losses of total soluble solids during the soaking of grains prior to germination (Wang et al., 1997). Crude fiber content has increased in millet flours after processing; similar results were observed by Shreeja et al. (2021), Gunashree et al. (2014) and Owheruo et al. (2019) in buckwheat, ragi and wheat, respectively. During the germination process, starch in the grain is broken down, and sugar is generally used up, leaving only the fibrous grain and this might cause an increase in fiber content (Ikenebomah $e t$ al., 1986; Shreeja et al., 2021).

Germination has significantly reduced fat content of barnyard and foxtail millet, it reduced by 7.3 and $17.84 \%$, respectively. At the same time, the germination has increased fat content of little millet flour by $25.95 \%$ (Figure 1). Reduced fat content was observed after germination in pearl millet, finger millet, sorghum (Singh et al., 2017), maize (Anaemene and Fadupin, 2020), wheat and ragi (Pandhre et al., 2011). Crude fat content increased after germination in brown rice (Xu et al., 2012), millet dakuwa and sorghum dakuwa (Nkama et al., 2015). Germination has shown non-significant decrease of carbohydrate content in barnyard and foxtail millet, while it significantly increased in foxtail millet (1.29\%). An increase in carbohydrate content was reported in germinated maize (Anaemene 
and Fadupin, 2020). Reduced carbohydrate content in germinated green gram was observed by Dattatray et al. (2019). Bello et al. (2017) reported non-significant increase in carbohydrate content at 24 and $48 \mathrm{~h}$ of germination and a significant decrease at $72 \mathrm{~h}$ of germination in pearl millet flour. Carbohydrate levels depend on moisture, ash, protein, fiber and fat content of the grains. Reduction in moisture, ash, crude protein and fat may be attributed to rise carbohydrates in foxtail millet on germination. Germination has decreased energy content of barnyard and foxtail millet by 1.2 and $1.44 \%$, while it increased in little millet by $2.06 \%$. Significant rise of fat content in little millet and decrease in barnyard and foxtail millet on germination might be the reason for changes in energy value, as it contains about twice the energy values of protein and carbohydrate (Osborne and Voogt, 1978). A significant decrease in energy value was observed at 24, 48 and $72 \mathrm{~h}$ of germination time in a brown and yellow variety of tiger nut flour; which was attributed to an increase in alpha-amylase activity, which breaks down complex carbohydrates into simpler and more absorbable sugars which are utilized by the growing seedlings during the early stage of germination (Chinma et al., 2009)

Germination of barnyard, foxtail and little millet has significantly reduced oxalate content in foxtail and little millet by 33.9 and $15.9 \%$ (Figure 2). Suma and Urooj (2014) reported significant reduction in oxalate content by 24 and $48 \%$ in pearl millet varieties after germination. Germination has reduced large portions of oxalate content in brown rice (Nissar et al., 2017), maize (Anaemene and Fadupin, 2020) and horsegram (Pal et al., 2016; Handa et al., 2017). Reduction in oxalate content might be due to the activation of oxalate oxidase during the germination process, which breaks down oxalic acid into carbon dioxide and hydrogen peroxide, consequently releasing calcium (Murugkar et al, 2013). Germination has increased tannin content of all three millet flours, per cent increase in tannin content was 22.45 , 26.93 and 48.2 in GB, GF and GL, respectively. Tannin content of two germinated sorghum and pearl millet varieties were increased (Elkhier and Hamid, 2008; Pushparaj and Urooj, 2014). Tannin is concentrated in seed coat, which is not affected by the germination process, since the major food consumption was taken from the cotyledon. The remained cotyledon parts are less in weight compared with seed coat of germinated grains. Therefore, overall tannin content was raised (Elkhier and Hamid, 2008). Germination has shown significant changes in total phenolic content of millet flours, it increased in barnyard and foxtail millet flour by 58.47 and $23.75 \%$, whereas it decreased in little millet flour by $7.27 \%$. Germination has increased total phenols in brown rice (Nissar et al., 2017), corn (Sokrab et al., 2012), finger and pearl millet (Chauhan, 2017). It could be due to enzymatic release of bound phenols and an increase in the free forms due to the breakdown of the cell wall during germination (Nissar et al., 2017). Reduced total phenols in germinated pearl millet, finger millet, sorghum (Singh et al., 2017) and horse gram were observed (Pal et al., 2016; Handa et al., 2017). In contrast, Bello et al. (2017) observed increased polyphenol content at $24 \mathrm{~h}$ of germination and decreased at 48 and $72 \mathrm{~h}$ of germination in pearl millet flour. Total flavonoid content has significantly increased in barnyard, foxtail and little millet on germination. Increased flavonoids were observed in germinated horsegram flour (Ojha et al., 2020). Phenols and flavonoids have potential applications in food, pharmaceutical and medical aspects, especially for antioxidant effects, antibacterial effect, anticancer effect, cardioprotective effects, immune system promoting and anti-inflammatory effects (Landete, 2012; Tungmunnithum et al., 2018).
DPPH free radical scavenging activity was studied at six different concentrations $(1,2,4,6,8$ and $10 \mathrm{mg} / \mathrm{ml})$. Free radical scavenging activity varied with the treatment and was concentration dependent in millet flours. $\mathrm{IC}_{50}$ values of germinated millet flours were increased, where low $\mathrm{IC}_{50}$ value indicates high antioxidant activity because it requires lower amount of antioxidants to scavenge $50 \%$ of free radicals. Zhang et al. (2015) observed similar results in germinated buckwheat. Little millet has the lowest $\mathrm{IC}_{50}$ value followed by barnyard and millet among raw and germinated millets. Germination has significantly increased radical scavenging activity of millet flours. This might be due to the decomposition of high molecular weight polymers during germination leads to the generation of biofunctional substances. Radical scavenging activity was highest in little millet followed by barnyard and foxtail millet flours among raw and germinated millet flours. Increased DPPH inhibition was observed after germination in brown rice (Nissar et al., 2017) and horsegram flour (Ojha et al., 2020).

\section{Conclusion}

The present research work results reveal that germination has shown significant changes in barnyard, foxtail, and little millet; however, the nutrient content is grain dependent. Germination has increased protein, fiber and tannins in barnyard millet; crude fiber, carbohydrate and tannins in foxtail millet and fat, energy value and tannins in little millet. In addition, germination has increased phenolic, flavonoid contents and radical scavenging activity in all millet flours. This improved bioactive compounds and antioxidant activity suggests developing a nutrient rich product with germinated millet flours for therapeutic diets. However, future studies are needed to carry out human health outcomes.

\section{Acknowledgements}

We wish to acknowledge the Department of Food and Nutrition, Central Instrumentation Cell and Millet Processing Incubation Centre of Professor Jayashankar Telangana State Agricultural University for the use of their facilities.

\section{Conflict of interest}

The authors declare that there are no conflicts of interest relevant to this article.

\section{References}

Al-Mudaris, M. A. (1998). Notes on various parameters recording the speed of seed germination. Der Tropenlandwirt-Journal of Agriculture in the Tropics and Subtropics, 99(2): 147-154.

Anaemene, D. I. and Fadupin, G. T. (2020). Effect of fermentation, germination and combined germination-fermentation processing methods on the nutrient and antinutrient contents of quality protein maize (QPM) seeds. Journal of Applied Sciences and Environmental Management, 24(9):1625-1630.

AOAC. (2005). Official Methods of Analysis for ash in flour. Association of Official Analytical Chemists. 18th Ed. Arlington VA 2209, USA. AOAC 929.09, chap 32, pp:01.

AOAC. (2005). Official Methods of Analysis for moisture in flour. Association of Official Analytical Chemists.18th Ed. Arlington VA 2209, USA. AOAC 929.03, chap 32, p02.

AOAC. (2005). Official Methods of Analysis for protein. Association of Official Analytical, Chemists. 18th ed. Arlington VA 2209, USA. AOAC 984.13, 04(31). 
AOAC. (2016). 922.06 and 2003.06 - Crude fat in Feeds, Cereal grains and forages; Randall/Soxtec/Hexanes Extraction-Submersion method, Official Methods of Analysis of the Association of Analytical Chemists. 20 ${ }^{\text {th }}$ edition (Volume-1 and 2). Association of official Analytical Chemists, International, Suite 500, 481, North Frederick Avenue, Maryland, 20877-2417, U.S.A.

AOAC. (2016). 962.09-Crude fibre analysis in feeds by filter bag technique - Official Methods of Analysis of the Association of Analytical Chemists. $20^{\text {th }}$ edition (Volume-1 and 2). Association of Official Analytical Chemists, International, Suite 500, 481, North Frederick Avenue, Maryland, 20877-2417, U.S.A.

Arora, P.; Sehgal, S. and Kawatra, A. (2003). Content and HCl-extractability of minerals as affected by acid treatment of pearl millet. Food Chemistry, 80(1):141-144.

Badau, M. H.; Nkama, I. and Jideani, I. A. (2005). Phytic acid content and hydrochloric acid extractability of minerals in pearl millet as affected by germination time and cultivar. Food Chemistry, 92(3):425-435.

Bello, F. A.; Enidiok, S. E. and Azubuine, B. C. (2017). Effect of steeping and sprouting on the nutritional, antinutritional and functional properties of pear millet (Pennisetum glaucum) starch. International Journal of Advanced Research in Science, Engineering and Technology, 4(9):4465-4471.

Chauhan, E.S.(2017). Antioxidant properties of germinated millets (Eleusine coracana and Pennisetum glaucum): A comparative study. International Journal of Food Science and Nutrition, 2:7578 .

Chinma, C. E.; Adewuyi, O. and Abu, J. O. (2009). Effect of germination on the chemical, functional and pasting properties of flour from brown and yellow varieties of tigernut (Cyperus esculentus). Food Research International, 42(8):1004-1009.

Correia, I.; Nunes, A.; Barros, A. S. and Delgadillo, I. (2008). Protein profile and malt activity during sorghum germination. Journal of the Science of Food and Agriculture, 88(15):2598-2605.

Correia, I.; Nunes, A.; Barros, A. S. and Delgadillo, I. (2010). Comparison of the effects induced by different processing methods on sorghum proteins. Journal of Cereal Science, 51(1):146-151.

Dattatray, T. R.; Monica, O.; Babu, A. S. and Jaganmohan, R. (2019). Effect of soaking time on sprouting and rheological properties of green gram. Int. J. Pure App. Bio. Sci., 7(3):181-188.

Dicko, M. H.; Gruppen, H.; Zouzouho, O. C.; Traoré, A. S.; Van Berkel, W. J. and Voragen, A. G. (2006). Effects of germination on the activities of amylases and phenolic enzymes in sorghum varieties grouped according to food end use properties. Journal of the Science of Food and Agriculture, 86(6):953-963.

Dorman H. J.; Bachmayer, O.; Kosar, M. and Hiltunen, R. (2004). Antioxidant properties of aqueous extracts from selected laminaceae species grown in Turkey, Journal of Agricultural and Food Chemistry, 52:762-770

Elkhier, M. K. S. and Hamid, A. O. (2008). Effect of malting on the chemical constituents, antinutrition factors and ash composition of two sorghum cultivars (feterita and tabat) grown in Sudan. Research Journal of Agriculture and Biological Sciences, 4(5):500-504.

Elmaki, H. B.; Babiker, E. E. and El Tinay, A. H. (1999). Changes in chemical composition, grain malting, starch and tannin contents and protein digestibility during germination of sorghum cultivars. Food Chemistry, 64(3):331-336.

Gunashree, B. S.; Kumar, R. S.; Roobini, R. and Venkateswaran, G. (2014). Nutrients and antinutrients of ragi and wheat as influenced by traditional processes. International Journal of Current Microbiology and Applied Sciences, 3(7):720-736.
Handa, V.; Kumar, V.; Panghal, A.; Suri, S. and Kaur, J. (2017). Effect of soaking and germination on physicochemical and functional attributes of horsegram flour. Journal of Food Science and Technology, 54(13):4229-4239.

Ikenebomeh, M. J.; Kok, R. and Ingram, J. M. (1986). Processing and fermentation of the African locust bean (Parkia filicoidea Welw.) to produce dawadawa. Journal of the Science of Food and Agriculture, 37(3):273-282.

Inyang, C. U and Zakari, U. M. (2008). Effect of germination and fermentation of pearl millet on proximate, chemical and sensory properties of instant "Fura"-a Nigerian cereal food. Pakistan Journal of Nutrition, 7(1):9-12.

Kalam Azad, M. O.; Jeong, D. I.; Adnan, M.; Salitxay, T.; Heo, J. W.; Naznin, M. T. and Park, C. H. (2019). Effect of different processing methods on the accumulation of the phenolic compounds and antioxidant profile of broomcorn millet (Panicum miliaceum L.). Flour Foods, 8(7):230.

Kayodé,A. P.; Linnemann, A. R.; Nout, M. J. and Van Boekel, M. A. (2007). Impact of sorghum processing on phytate, phenolic compounds and in vitro solubility of iron and zinc in thick porridges. Journal of the Science of Food and Agriculture, 87(5):832-838.

Khokhar, S. and Apenten, R.K.O. (2003). Antinutritional factors in food legumes and effects of processing. The Role of Food, Agriculture, Forestry and Fisheries in Human Nutrition, 4:82-116.

Landete, J. M. (2012). Updated knowledge about polyphenols: Functions, bioavailability, metabolism, and health. Critical Reviews in Food Science and Nutrition, 52(10):936-948

Meda A.; Lamicn C.E.; Romito M.; Millogo, J. and Nacoulma, O.G. (2005). Determination of the total phenolic, flavonoid and proline contents in Burkina fasan honey, as well as their radical scavenging activity, Food Chemistry, 91:571-577

Murugkar, D. A.; Gulati, P. and Gupta, C. (2013). Effect of sprouting on physical properties and functional and nutritional components of multinutrient mixes. International Journal of Food and Nutritional Sciences, 2(2):8.

Nazni, P. and Shobana, D. R. (2016). Effect of processing on the characteristics changes in barnyard and foxtail millet. Journal of Food Processing and Technology, 7(3):1-9

Nissar, N.; Wani, S. M.; Hameed, O. B.; Wani, T.A and Ahmad, M. (2017). Influence of paddy (Oryza sativa) sprouting on antioxidant activity, nutritional and anti-nutritional properties. Journal of Food Measurement and Characterization, 11(4): 1844-1850.

Nkama, I.; Gbenyi, D. I and Hamaker, B. R. (2015). Effects of malting and roasting of millet and sorghum on protein digestibility, mineral availability, soluble sugar composition and consumer acceptability of Dakuwa. Indian Journal of Nutrition, 2(1):1-6.

NWASIKE, C.C. (1989). Effect of cultivar, steeping, and malting on tannin, total polyphenol, and cyanide content of Nigerian sorghum. Cereal Chem., 66(2):87-89.

Ojha, P.; Bhurtel, Y.; Karki, R and Subedi, U. (2020). Processing effects on antinutritional factors, phytochemicals, and functional properties of horse gram (Macrotyloma uniflorum) flour. Journal of Microbiology, Biotechnology and Food Sciences, 9(6):1080-1086.

Okoh, S. O.; Asekun, O. T.; Familoni, O. B and Afolayan, A. J. (2014). Antioxidant and free radical scavenging capacity of seed and shell essential oils extracted from Abrus precatorius (L). Antioxidants, 3(2):278-287.

Osborne, D. R and Voogt, P. I. (1978). The analysis of nutrients in foods. Academic Press Inc. (London) Ltd., 24/28 Oval Road, London NW1 7DX. (P-128). 
Owheruo, J. O.; Ifesan, B. O. and Kolawole, A. O. (2019). Physicochemical properties of malted finger millet (Eleusine coracana) and pearl millet (Pennisetum glaucum). Food Science and Nutrition, 7(2):476482 .

Pal, R. S.; Bhartiya, A.; ArunKumar, R.; Kant, L.; Aditya, J. P and Bisht, J. K. (2016). Impact of dehulling and germination on nutrients, antinutrients, and antioxidant properties in horsegram. Journal of Food Science and Technology, 53(1):337-347.

Pandhre, G. R.; Satwase, A. N. and Hashmi, A. I. (2011). Studies on drying characteristics and nutritional composition of sprouted wheat and finger millet. International Journal of Current Research, 3(7):218221

Pushparaj, F. S. and Urooj, A. (2014). Antioxidant activity in two pearl millet (Pennisetum typhoideum) cultivars as influenced by processing. Antioxidants, 3(1):55-66.

Ragaee, S.; Abdel-Aal, E. S. M and Noaman, M. (2006). Antioxidant activity and nutrient composition of selected cereals for food use. Food Chemistry, 98(1):32-38.

Rao, B. R.; Nagasampige, M. H and Ravikiran, M. (2011). Evaluation of nutraceutical properties of selected small millets. Journal of Pharmacy and Bioallied Sciences, 3(2):277.

Sade, F.O. (2009). Proximate, antinutritional factors and functional properties of processed pearl millet (Pennisetum glaucum). Journal of Food Technology, 7(3):92-97.

Saleh, A. S.; Zhang, Q.; Chen, J. and Shen, Q. (2013). Millet grains: Nutritional quality, processing, and potential health benefits. Comprehensive Reviews in Food Science and Food Safety, 12(3):281-295.

Sen, S.; Chakraborty, R.; Sridhar, C.; Reddy, Y.S. R. and De, B. (2010). Free radicals, antioxidants, diseases and phytomedicines: current status and future prospect. International Journal of Pharmaceutical Sciences Review and Research, 3(1):91-100.

Shashi, B. K.; Sharan, S.; Shittalamani, S.; Shankar, A. G and Nagarathna, T. K. (2007). Micronutrient composition, antinutritional factors and bioaccessibility of iron in different finger millet (Eleusine coracana) genotypes. Karnataka Journal of Agricultural Sciences, 20(3):583585 .
Sheela, P.; UmaMaheswari, T.; Kanchana, S.; Kamalasundari, S. and Hemalatha, G. (2018). Development and evaluation of fermented millet milk based curd. J. Pharmacog. Phytochem, 7:714-717.

Shreeja, K.; Devi, S. S.; Suneetha, W. J and Prabhakar, B. N. (2021). Effect of germination on nutritional composition of common buckwheat (Fagopyrum esculentum Moench). International Research Journal of Pure and Applied Chemistry, 22(1):1-7.

Singh, A.; Gupta, S.; Kaur, R. and Gupta, H. R. (2017). Process optimization for antinutrient minimization of millets. Asian Journal of Dairy and Food Research, 36(4).

Slinkard, K. and Singleton V. L. (1997). Total phenol analysis, automation and comparison with manual methods, American Journal of Ecology and Viticulture, 28:49-55

Sokrab, A. M.; Ahmed, I. A. M. and Babiker, E. E. (2012). Effect of germination on antinutritional factors, total, and extractable minerals of high and low phytate corn (Zea mays L.) genotypes. Journal of the Saudi Society of Agricultural Sciences, 11(2):123-128.

Sreeramulu, D.; Reddy, C. and Raghunath, M. (2009). Antioxidant activity of commonly consumed cereals, millets, pulses and legumes in India. Indian Journal of Biochemistry and Biophysics, 46:112-115.

Suma, P. F. and Urooj, A. (2014). Influence of germination on bioaccessible iron and calcium in pearl millet (Pennisetum typhoideum). Journal of Food Science and Technology, 51(5):976-981.

Tungmunnithum, D.; Thongboonyou, A.; Pholboon, A. and Yangsabai, A. (2018). Flavonoids and other phenolic compounds from medicinal plants for pharmaceutical and medical aspects: An overview. Medicines, 5(3):93.

Wang, N.; Lewis, M. J.; Brennan, J. G. and Westby, A. (1997). Effect of processing methods on nutrients and antinutritional factors in cowpea. Food Chemistry, 58(1-2):59-68.

Xu, J.; Zhang, H.; Guo, X. and Qian, H. (2012). The impact of germination on the characteristics of brown rice flour and starch. Journal of the Science of Food and Agriculture, 92(2):380-387.

Zhang, G.; Xu, Z.; Gao, Y.; Huang, X.; Zou, Y. and Yang, T. (2015). Effects of germination on the nutritional properties, phenolic profiles, and antioxidant activities of buckwheat. Journal of Food Science, 80(5):H1111-H1119. 